\title{
To Which Extent the Red Terror Affects People in Soviet Union The Red Terror: Necessary Policy or Intentional Murders?
}

\author{
Chen Xue
}

Sendelta International Academy, Shenzhen, 518108

18923376265@163.com

\begin{abstract}
Although Soviet Union had played a crucial role in human society in the last century, few have discussed the country's history at early stage. In the paper, the history background of early Soviet Union by the end of Russian civil war, the time period of well-known "The Red Terror" and its effect on Russian people will be discussed. Because of the reasons that based on the extreme situation and conditions in front of both soviet leaders and Russian people were harsh, it is suggesting that this phenomenon we called as "Red Terror" which has a wide-range long been described in Western World as the symbol of tyranny of communism, was actually essential in stabilizing Russia. Such researches can be useful to correct people's common mistakes over this familiar topic "The Red Terror".
\end{abstract}

Keywords: Soviet Union, History, The Red Terror

\section{INTRODUCTION}

At present days, due to the gap between history and general people, the public's understandings towards Soviet Union are usually shaped by movies, novels and unreliable news. The fact that there used to be a kind of Red Terror becomes widely known among people, while few of them can say that they are confident in what exactly happened during that time period. What happened during the Russian Civil War? The great purge? Or the second World War? When exactly the red terror took place? Were those cool-blooded murders true? It is hard to find it out. I want to figure out if these ideas were true and if so, beneficial or not, generally. To answer this question, we shall look back to the documents a century ago, to find out how the lives were like during that time period, and to understand the situation which Soviet Union was facing.

In this paper, it argues that the Red Terror is more like a necessary action that unluckily causes unintentional harm. The concept of the Red Terror, in this paper, refers to the time period of Lenin's rule, started since 1917 and ended as Lenin passed away. It is hard to say that policy similar to what we called The Red Terror happens in $21^{\text {st }}$ century, thus, understanding the so-called "terrorism" or "inhuman" policies helped us to clarify the historic facts and learn from the experience of past revolution.

\section{BEFORE THE REVOLUTION}

After the Victory of October Revolution in 1917, this overwhelming revolutionary wave across the entire Russia did not stop. The transition was not as peaceful as the one took place few years before when the February Revolution broke out. Different from people's enthusiasm, the reality of Russia was not optimistic enough for the revolution to go on a expected way.

Before the revolution broke out, the Russian society was terribly carved up by what communists called bourgeoisie. When the bloody World War happens, Russians had to deal with starvation because Russian Empire failed to industrialize the country. The starvation lasts for years and the society fell into Chaos, this became one of the most difficult problems that the revolutionists had to deal with. Especially after the World War, when western countries such as the UK were able to extract themselves out of the World War, they started to intervene the Russia Civil War and even sent the troops to stop the Red Army. Despite the foreign intervention, the Red Army itself could not sustain itself that they had to start a Surplus grain collection system, which was regarded as a part of the Red Terror. 
Before the revolution, back to 1905 , in order to ease domestic social struggle and fought for the sphere of influence, Tsarist Russia and the Japanese Empire engaged to a war, which turned out to be terrible. The failure of Russia ignited internal conflicts and led to several rebellions. The tsar had no choice but to compromise to the public and gave the people certain rights to participate in politics through Duma. This stabilized Russia for a while, but the world did not really give Russia the time to rest.

During the World War, in the eastern front, although some victories were made when encountering the Austrians, Russian Army could not defeat the attack of Germany troops. In order to maintain the army, Russian government had to forced peasants to provide supplies and joined the army, which also harmed Russian society greatly because of the lack of labor in the countryside, this also stimulated the starvation.

\section{THE RED TERROR}

After the victory of the October Revolution, supported by foreign power, landlords and bourgeoise in Russia started to fight against the Soviet government. They opposed all aspects of the Soviet regime and policies, disrupted industrial production, created food crises, and continually launched military rebellions to directly fight against the government. In order to suppress the rebellions and stabilized the newly soviet government, Cheka was created. The wide rights given to Cheka that they were able to supervise all aspects of people and take actions without legislation concerns created what we called The Red Terror. Though Cheka was the basis of NKVD, later political struggle in the Soviet Union and the great purge was not a part of the Red Terror that's been discussing here, and the Red Terror here mostly refers to the elimination of counterrevolutionaries happened during Lenin's rule.

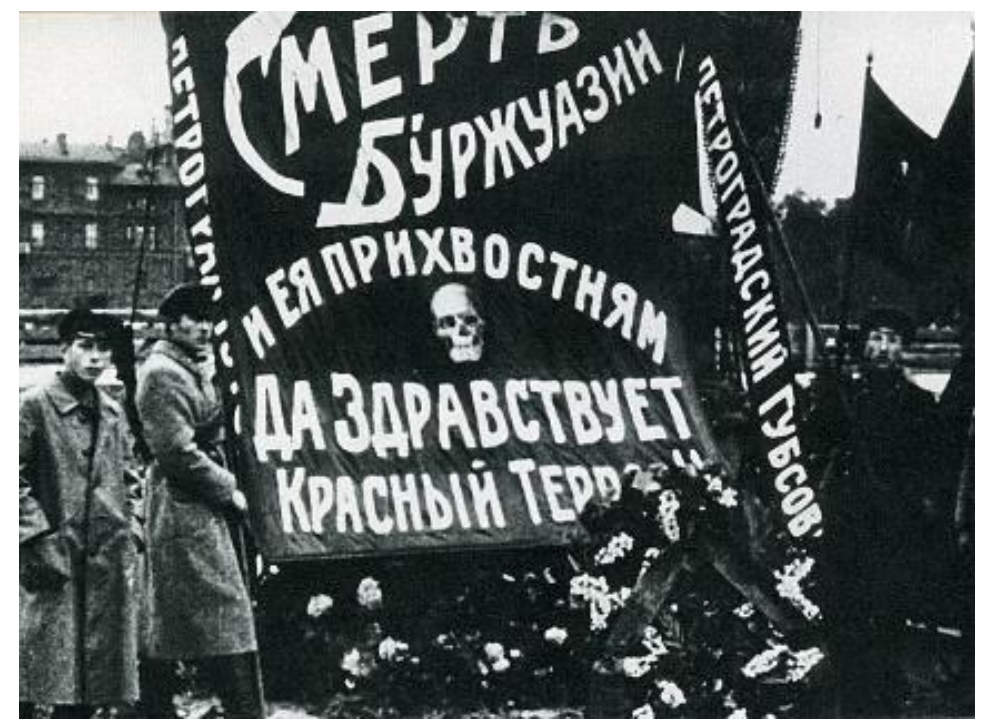

Figure 1: Propaganda poster in Petrograd, 1918: "Death to the Bourgeoisie and its lapdogs - Long live the Red Terror" (1)(Image source: scan from Knigge, Scherbakowa: GULAG - Spuren und Zeugnisse 1929- 1956, p. 16, collection "Memorial", Moscow)

\section{THE ENEMIES ON THE BATTLEFIELD}

During and after the civil war, the red army had to struggle to fight endless rebellions from almost the entire world including the Russian people themselves. From the white army they fought against during the October Revolution, to the black army they once cooperated with, to the farmers who fought against the surplus gain collection system, to the rebellions organized by the Czechoslovak people. Due to the facts that the Red Army was a highly immature army that could not defeat any professional military power, strict laws were promoted as a way to defeat the new government.

The army forces organized by the early Bolsheviks were much different from those of the conventional powers held by other superpowers. Due to the doctrine of the socialist revolution of the October Revolution, the organization of the early Bolsheviks' army was just opposite from that of the white army one the other side of the civil war, for it was a non-professional armed force composed of the proletarian people. Marxists believe that a standing army is a product of private ownership; In a socialist country under the dictatorship of the proletariat, the proletarian army is supposed to be organized in the form of a dispersed militia [1]. The early Bolshevik leadership accepted and adopted this idea, promoting the abolition of the standing army on the platform of the Second Congress of the Russian Social Democratic Labor Party in 1903[1]. However, its post-October Revolution decree of establishing a militia Red Army turned out to be puny in front of attacks from the opposition, the lack of effective organization of the Red Army made it impossible for the central government to organize the army, which allowed the German-Austrian coalition to take advantage, and for a time they even 
pushed the front as far as Petrograd. Under these circumstances, the Red Army could hardly resist a foreign invasion, let alone winning the civil war and establish a Soviet Russia.

The weakness of the Red Army gave their enemies the chance to expand their influence. At the end of 1917, Lenin assigned Dzerzhinsky to organized Cheka to deal with the rebellions and counterproductive job behaviors.

In the later period of Tsarist Russia, as a country at the point of social transformation or modernization, its failed modernization reforms and the backwardness, decay and incompetence of the conservative power caused sharp social contradictions and gave birth to the socialist revolution, but it also brought about a chaotic society [2]. The new socialist government could not control the peasants quickly or effectively. Moreover, Russia itself was not a strong industrial power, so the Red Army had to rely on private property or seized equipment to fight. As mentioned in the previous passages, the Red Army sometimes have to rub food from local people in order to gain more supplies. Thus, the Red Army was not trusted by many people at the grass-roots level, and its strength was therefore severely limited. Lenin, the leader of the Soviet Union, showed worries towards this situation and invited a large French military delegation from Romania to Moscow to assist in the training of the Red Army. Even if the facts had proved clearly that using the militia to replace the professional army was impossible, the transition from militias to a professional army still, was a hard task.

Trotsky, who became the president of the Supreme Military Council on March 19, 1918, initially advocated a militia just like how others believed in. However, after several military defeats in the early years of the Civil War, he recognized the urgent need for an organized and disciplined regular army. He himself lamented the lack of organization and discipline, and said: "A real army cannot be led by an elected committee and officers who can be removed at any time by their subordinates." "The soldiers' committee is not the essence of the revolution...A council of soldiers cannot command a brigade."[1]. Trotsky then persuaded the Central Committee to implement his idea by replacing the election system with the appointment system [1], which turned out to be useful but inadequate. When Trotsky heard about the desertion of the commissars on the Volga River and came to the area, he was so angry that he decided to take a much tougher approach: the commissar and commander in charge of withdrawing troops would be shot. The commissar who had fled was arrested and executed. Trotsky also moved a great deal of weaponry. "Without revolvers," he reasoned, "the situation at the front is such a mess that discipline cannot be maintained."[1].
To sum up, Trotsky successfully reorganized and improved the Red Army of the Soviet Union and played a significant role in safeguarding the fruits of the Communist revolution through a cruel and violent way. The result of the more professional red army turned out to be successful, for Soviet government successfully become the winner of the Civil War after all those interventions. Although the concept of the Red Terror refers more to the suppression politically, what happened in the army could be regarded as the origin and experiment of what would take place later. Some of Trotsky's ideas, including the stopping the local election and replace it with appointment system, were adopted by Cheka in the later actions such as controlling the factories. These policies effectively expanded the power of the Central Committee of the Communist Party of Russia, and the scope of application of these measures was further expanded in the future.

\section{THE POLITICAL SUPPRESSION}

During the Russian Civil War between the summer of 1918 and the end of 1920, the Cheka's work focused more on assisting and protecting the logistics of Red Army troops on the front line. When the Red Army gained more control over Russia, their enemies did not give up their pursuit of their own interests. The penetration of foreign forces enabled the opposition to destroy the industrial production of Soviet Russia, create famines or directly launch military rebellion [3]. As clearly mentioned in the full name of Cheka, "eliminating counter-revolution and sabotage", despite dealing with the subversive activities against the Soviet government held by Constitutional Democratic Party, the Left Party of the Social Revolution and foreign infiltrating forces, and effectively cracking down on food speculation within the country, the Cheka also had to deal with opposing sabotages in factories [4]. Because of these tasks put on Cheka's shoulder and the unlimited rights given, what we called the Red Terror had begun.

Lenin wanted Cheka to be strong, swift, and resolute. He insisted on the arrests of those who disagreed with the policies made by the central government, members such as those of the leadership of the Constitutional Democratic Party were on the list. The constituent assembly elections held before the October revolution cannot really reflect the interests of the people, according to Lenin, it was lack of credibility because the Russia was at a very different location after the October revolution [4]. The crisis caused by the election was solved by the Soviet government, so meeting the final discussion results must follow the Soviet central all the laws and regulations. In addition to defend the attacks of foreign power and counterrevolutionary parties, Lenin had also acted tough on reactionaries who sabotage work or sabotage production. 


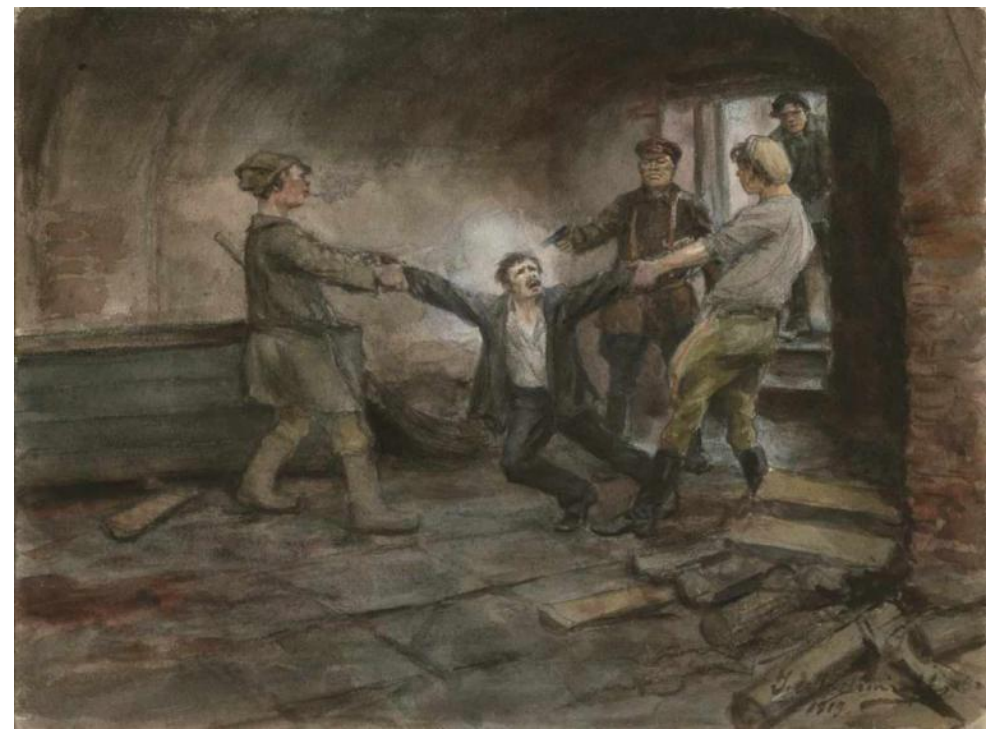

Figure 2 "In the basements of a Cheka", by Ivan Vladimirov (2)(Image source: https://www.wikiart.org/en/ivanvladimirov/all-works)

However, rather than overseeing labor in the rear as Trotsky had planned, Cheka's actions were more akin to "using terror against hostile forces" rather than indiscriminately supervising the work. In addition to the fact that Lenin hoped to adopt the most resolute and forceful revolutionary means mentioned in the previous paragraphs, he also made an effort in the idea of preventing unjust, false and wrong cases. After the establishment of the revolutionary court, Lenin believed that "once the revolutionary court is established, it should immediately review every case of forced Labor, either confirm the duration of the Labor or release the arrested person. "[4] In order to crack down the unjust, wrong and erroneous judgement and guarantee the legitimate rights and interests of the working class, Lenin proposed that the Committee should step up its work to prevent the use of anonymous letters without providing evidence to attack others and to protect the people's right to appeal.

Moreover, as for Lenin, it was a matter of considerable concern to ensure that the revolutionary teams themselves did not go wrong. In terms of military affairs, the Soviet Red Army did recruit officers from the Tsarist Russia in exchange to quickly build up a modernized and professional army. However, when the problem encountered ideology, the Cheka did not show any mercy to the counter-revolutionaries. The measures adopted by Cheka facilitated to establish the authority of the Soviet Union and effectively reduced the amount of sabotage. Lenin argued that the "terror" intentionally created by Cheka must be used to fight against counterrevolutionaries. For example, confiscating the grain stockpile of rich peasants and suppressing their riots, while those who tried to hide it would be carefully investigated and "severely punished". In the Soviet Union at that time, not many people met the conditions of the rich peasants. In dealing with the middle peasants, the Soviet Union proposed a policy of cooperation rather than direct suppression.

During the famine period, the Soviet Union proposed to establish a grain collection army with clear regulations and strict management to prevent any reactionary elements distracted the process of work. It was also required to include personnel who carried out the instructions unconditionally and resolutely obeyed the orders of the leaders. In addition, it effectively differentiated the targets of grain collection to prevent unjust, false and wrong cases from taking place. Welltrained troops became the national standard. Apart from terror, this reliance on positive revolutionary propaganda to achieve the purpose of stabilizing the state was also one of the Soviet Union's methods of war supervision. 


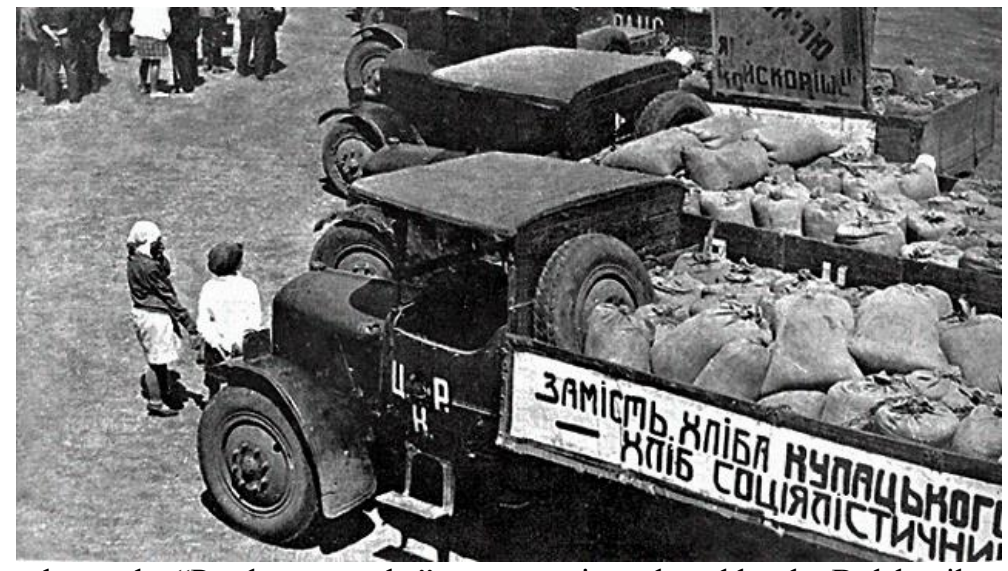

Figure 3 A picture that shows the "Prodrazvyorstka", a system introduced by the Bolshevik government to deal with the famine by confiscating of grain and other agricultural products from peasants at a fixed price based on specified quotas. The words on the Soviet requisition vehicle: "Instead of kulak bread - [we bring you] Socialist bread. (3)

(Image Source : CPA Media Pte Ltd / Alamy Stock Photo)

In the late period of the Soviet Union's civil war, the state had been gradually stabilized. As the situation changed, the strategies of the Soviet Union's national security organs also changed. From using terror to crack down on counterrevolutionaries and maintain domestic production, to using social propaganda to appeal to the public and weaken the power of the secret police. And this declared the end of the Red Terror.

\section{CONCLUSION}

To sum up, during the period of the Russia civil war, because of the reasons that based on the extreme situation and conditions in front of both soviet leaders and Russian people were harsh, it is suggesting that this phenomenon we called as "Red Terror" which has a wide-range long been described in Western World as the symbol of tyranny of communism, was actually essential in stabilizing Russia. Though unnecessary harm was caused, in order to avoid greater harm, the policies published during this time period was highly restricted in several aspects.

\section{REFERENCES}

[1] Xiaogang Lai. Trotsky and the foundation of the Red Army [J] World History. 1988(5):11-21.

[2] Zhonggui Liu. A Review of Stolypin striving for stability in the Last Stage of Tsar Russia [A]. Journal of Zhaoqing University. 2012, 33(6):58-63.

[3] Lei Zhu. A review of the problems of Soviet state security during the time period of new economic policy [A]. Academic Journal of Russian Studies. 2011(3):83-87.

[4] Liangzao Yu. Lenin's Politic ideas on Purges in early Soviet Russia [J]. Journal of Hubei University (Philosophy and Social Science). 1996(5):5-11. 